Neth. J. Pl. Path. 87 (1981) 25-29

\title{
Monitoring for cereal aphids in winter wheat
}

\author{
R. RABBINGE ${ }^{1}$ and W. P. MANTEL ${ }^{2}$ \\ 1 Department of Theoretical Production Ecology, Agricultural University, Wageningen, the \\ Netherlands \\ ${ }^{2}$ Research Institute for Plant Protection (IPO), Wageningen, the Netherlands
}

Accepted 21 May 1980

\begin{abstract}
A simple monitoring method for cereal aphids is described which diminishes observation time and can be used by farmers themselves. By repeated observations the farmers can follow the population upsurge of the aphids. A description of the yield decrease - aphid density relation is given which may help to decide whether control measures against cereal aphids are needed.
\end{abstract}

Additional keywords: Metopolophium dirhodum, Sitobion avenae, Rhopalosiphum padi, population dynamics.

The yearly rapid increase of cereal aphids requires continuous monitoring. However, continuous monitoring of aphids is a very time consuming procedure and therefore methods which reduce sampling and monitoring activities are urgently needed. Population models which simulate the population curve of the aphids from immigration until the flattening of the curve may help in this. Detailed population models of Sitobion avenae (Rabbinge et al., 1979, Carter et al., in prep.) explain the upsurge of the population and the period of flattening but are still inadequate in explaining completely the collapse of the aphid population. Based on a sensitivity analysis with these explanatory models, simple formulas were developed which are used to produce short term predictions (Rijsdijk et al., in prep.).

With these short term predictions of the population density of the aphids it is possible to determine at what time measures are needed to prevent the aphids from reaching density levels at which they may cause economic damage. Definition of the damage threshold (costs of treatment $=$ costs of potential yield loss) requires also knowledge of the level of yield loss and the way it is generated (Vereijken, 1979).

It appears that the relation between aphid numbers per ear in the peak and yield loss has a correlation coefficient of 0.75 (Vereijken, 1979). The maximum number of aphids per culm (main shoot and tillers) has a higher correlation coefficient and a slightly lower regression coefficient $(r=0.83 ; y=26.1 \times+8.02)$. Figure 1 based on an analysis of 20 experiments (PAGV, CABO, IPO*; ten Hag, de Vos and Ubels, pers. comm.) during the years 1974-1979 shows that Metopolophium dirhodum and S.avenae may cause considerable yield loss. Situations in which $M$. dirhodum

* Research Station for Arable Farming and Field Production of Vegetables (PAGV), Centre for Agrobiological Research (CABO), Research Institute for Plant Protection (IPO). 
Fig. 1. Relation between maximum number of cereal aphids per culm and loss of yield in winter wheat in $\mathrm{kg} / \mathrm{ha}(\mathrm{r}=0.83 ; \mathrm{y}=26.1 \times+8.02)$. The numbers refer to the yield (in 100 $\mathrm{kg} / \mathrm{ha}$ ) in the untreated plots.

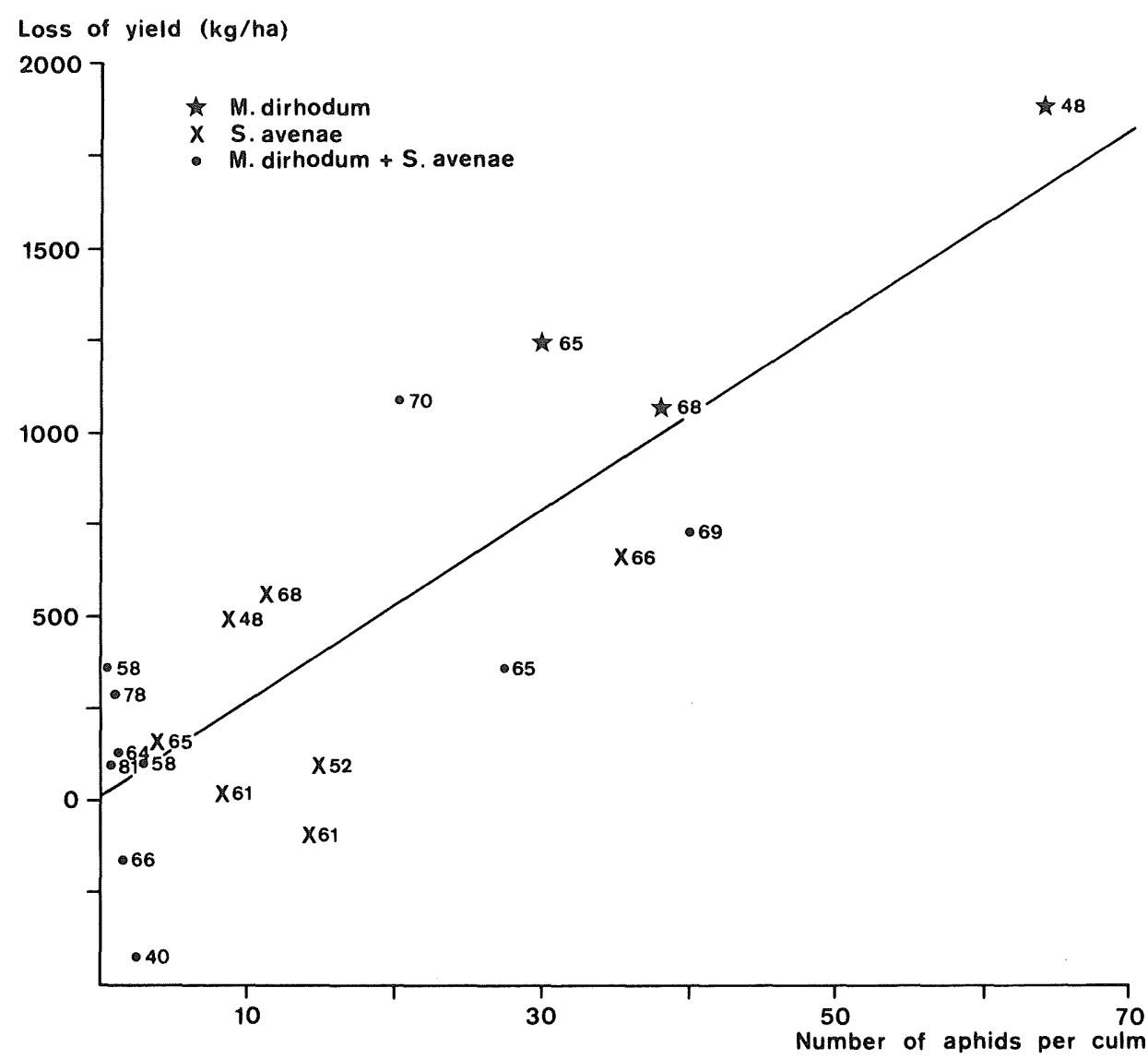

Fig. 1. Relatie tussen het maximum aantal graanbladluizen per halm en de opbrengstderving in wintertarwe in $\mathrm{kg} / \mathrm{ha}$. De getallen geven de opbrengst (in $100 \mathrm{~kg} / \mathrm{ha}$ ) in de onbehandelde veldjes.

$(>80 \%)$ or S.avenae dominates $(>80 \%)$ are indicated. This means that both 'leaf' aphids and 'ear' aphids may cause considerable yield loss. The correlation between aphid presence and yield loss does not improve when the accumulated aphid numbers multiplied with their presence (aphid days) is used instead of peak numbers Table 1).

Decision rules to initiate activity for control measures use this information together with predictive formulas of aphid numbers. To collect input data of aphid numbers for these predictive formulas a simple and reliable method of sampling aphids is needed. This method should be applicable for all cereal aphid species individually or in combination. To derive such a method, we considered the distribution of the aphids in the field during the years 1974-1979. The distribution characteristics 
Table 1. Relation between aphid density and yield loss in $\mathrm{kg} / \mathrm{ha}$.

\begin{tabular}{|c|c|c|c|c|}
\hline $\begin{array}{l}\text { Location of aphid } \\
\text { and species }\end{array}$ & 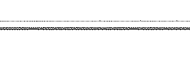 & Relation & $\begin{array}{l}\text { Correlation } \\
\text { coefficient }\end{array}$ & $\begin{array}{l}\text { Number } \\
\text { of cases }\end{array}$ \\
\hline $\begin{array}{l}\text { Metopolophium } \\
\text { dirhodum on leaves }\end{array}$ & $\begin{array}{l}\text { aphid days } \\
\text { peak density }\end{array}$ & $\begin{array}{l}y=1.54 \times+62.8 \\
y=22.8 \times+62.9\end{array}$ & $\begin{array}{l}0.30 \\
0.30\end{array}$ & $\begin{array}{l}8 \\
8\end{array}$ \\
\hline $\begin{array}{l}\text { Sitobion avenae } \\
\text { on leaves }\end{array}$ & $\begin{array}{l}\text { aphid days } \\
\text { peak density }\end{array}$ & $\begin{array}{l}y=11.5 x+87.5 \\
y=137 x+58.0\end{array}$ & $\begin{array}{l}0.76 \\
0.70\end{array}$ & $\begin{array}{l}8 \\
8\end{array}$ \\
\hline $\begin{array}{l}\text { All aphids on } \\
\text { leaves (S. avenae, } \\
M . \text { dirhodum, } \\
\text { Rhopalosiphum padi) }\end{array}$ & $\begin{array}{l}\text { aphid days } \\
\text { peak density }\end{array}$ & $\begin{array}{l}y=1.6 x+18.5 \\
y=28.7 \times+3.22\end{array}$ & $\begin{array}{l}0.41 \\
0.47\end{array}$ & $\begin{array}{l}8 \\
8\end{array}$ \\
\hline $\begin{array}{l}\text { All aphids on ears } \\
\text { (S. avenae }+R . \text { padi) }\end{array}$ & $\begin{array}{l}\text { aphid days } \\
\text { peak density }\end{array}$ & $\begin{array}{l}y=1.9 \times+85.9 \\
y=24.3 \times+66.7\end{array}$ & $\begin{array}{l}0.75 \\
0.74\end{array}$ & $\begin{array}{l}8 \\
8\end{array}$ \\
\hline $\begin{array}{l}\text { All aphids per } \\
\text { culm ( } S \text {. avenae, } \\
M . \text { dirhodum, } \\
R . \text { padi) }\end{array}$ & $\begin{array}{l}\text { aphid days } \\
\text { peak density }\end{array}$ & $\begin{array}{l}y=1.1 \times-71 \\
y=17.2 \times-79.9\end{array}$ & $\begin{array}{l}0.67 \\
0.72\end{array}$ & $\begin{array}{l}8 \\
8\end{array}$ \\
\hline
\end{tabular}

Tabel 1. Relatie tussen de bladluisdichtheid en de opbrengstderving in $\mathrm{kg} / \mathrm{ha}$.

for $S$. avenae, Rhopalosiphum padi and $M$. dirhodum on different parts and on the complete culm were investigated. It appears that for $S$. avenae the negative binomial distribution gives the best fit in most cases (200 out of 225) and that in 20 cases a Poisson distribution gives a better fit, whereas in only 5 cases a Neyman-A distribution gives the best fit. For $M$. dirhodum and $R$. padi this clustering is less clear, there are more cases in which a Poisson distribution gives a better fit. The distributions are similar whether the total culm or separate plant parts, as for example the ear or the flagleaf, are considered. Due to the clustered distribution of the aphids a double transformation of infestation level (the percentage of culms infested with aphids out of a sample) versus aphid density may result in a linear relationship (Pielou, 1969). In Table 2 the relation between the probit value of the infestation level of culms (number of infested culms out of 100 inspected culms) and the logarithm of the average number of aphids per culm is given. It shows that the relation is linear (correlation coefficient $=0.93$ ). Similar relations are found for the individual species and for different plant parts. In all cases the correlation coefficient exceeds 0.92 and the regression coefficient for all determined relations varies scarcely (Rabbinge et al., 1980). This enables the use of the same regression line for all cases.

Sampling activities can now be reduced because only the infestation level needs determination, which is used to find the average number of aphids per culm, ear or on the leaves per culm. With simple predictive formulas the peak density may be predicted and the expected yield loss may be calculated from the relation between peak density and yield loss. Thus, the decision is made whether the action threshold will be exceeded and a warning should be given.

Neth. J. Pl. Path. 87 (1981) 
Table 2. Relation between probit value of infestation level of the culms and logarithm of number of aphids per culm, on leaves only or on ears only (1974-1979).

\begin{tabular}{|c|c|c|c|}
\hline Relation & Regression line & $\begin{array}{l}\text { Correlation } \\
\text { coefficient }\end{array}$ & $\begin{array}{l}\text { Number of } \\
\text { cases }\end{array}$ \\
\hline $\begin{array}{l}\text { Probit value percentage } \\
\text { infested culms versus } \\
\text { log total number of } \\
\text { M.dirhodum per culm }\end{array}$ & probit $y=1.40 \log x+4.35$ & 0.92 & 162 \\
\hline $\begin{array}{l}\text { Probit value percentage } \\
\text { infested culms versus } \\
\text { log total number of } \\
M . \text { dirhodum, } R \text {. padi } \\
\text { and S.avenae per culm, } \\
\text { leaves only }\end{array}$ & probit $y=1.34 \log x+4.49$ & 0.92 & 241 \\
\hline $\begin{array}{l}\text { Probit value percentage } \\
\text { infested culms versus } \\
\log \text { total number of } \\
\text { M. dirhodum, } R \text {. padi and } \\
S . \text { avenae per culm }\end{array}$ & probit $y=1.51 \log x+4.63$ & 0.93 & 229 \\
\hline $\begin{array}{l}\text { Probit value percentage } \\
\text { infested ears versus } \\
\text { log total number of } R . \text { padi } \\
\text { and S.avenae per ear }\end{array}$ & probit $y=1.54 \log x+4.62$ & 0.92 & 215 \\
\hline
\end{tabular}

Tabel 2. Relatie tussen de logaritme van het aantal bladluizen per halm (stengel, bladeren en aar), per aar of alleen op de bladeren en de waarschijnlijkheidswaarde van het percentage met bladluizen bezette halmen (1974-1979).

A weak part in this warning and decision procedure is the low correlation between aphid numbers and yield loss. Although the relation for the total culm is considerably better than for the ears only, the relation explains only two third of the cases $(r=0.83 ; \mathrm{r}=0.68)$. Moreover, a correlative relation does not give the biological background of damage. In this case the implicit assumptions are made of a linear relation between aphid density and yield loss and on homoscedasticity. Both assumptions may be invalid. Detailed studies of the nature of damage show that direct suction damage explains about $45 \%$ of the yield loss (Vereijken, 1979). The remaining. damage is probably caused by secondary effects induced by honeydew and saliva injection. Honeydew stimulates secondary perthotrofic fungi (Fokkema et al., 1979) and hampers photosynthetic activity (Rabbinge et al., in prep.). Moreover, leaf senescence is promoted by direct suction activity of the aphids and by honeydew (Wratten, 1975, Rabbinge et al., 1979). The relative contribution of each of these effects may vary depending on weather conditions and plant condition. Therefore, it is very difficult to determine a fixed relation between aphid pressure and resulting yield losses. For this reason it seems more appropriate for damage predictions to use combination models of crop growth and aphid population dynamics into which all 
the effects mentioned and their dependence on environmental conditions have been incorporated (Rabbinge et al., in prep.).

\section{Samenvatting}

\section{Waarnemen van bladluizen in wintertarwe}

Uit een evaluatie van veldproeven die gedurende de laatste jaren werden verricht is gebleken dat de in wintertarwe het frekwentst voorkomende bladluizensoorten $\mathrm{Me}$ topolophium dirhodum en Sitobion avenae, zowel in combinatie als per soort afzonderlijk flinke oogstreducties in $\mathrm{kg} / \mathrm{ha}$ kunnen veroorzaken. De opbrengstderving wordt veroorzaakt door een combinatie van directe zuigschade door de bladluizen, honingdauwafscheiding en de wijziging in verouderingssnelheid en netto assimilatie van de bladeren.

Een eenvoudige waarnemingsmethode voor bladluizen in wintertarwe wordt beschreven, welke de waarnemingstijd vermindert en door de telers zelf kan worden gebruikt. Door herhaling van de waarnemingen kan de teler de populatieopbouw van de bladluizen volgen. Een beschrijving van de relaties tussen bladluizendichtheid en opbrengstderving is gegeven. Deze kan behulpzaam zijn bij het nemen van een beslissing over bestrijdingsmaatregelen.

\section{References}

Carter, N., Rabbinge, R. \& Dixon, A. F. G. Cereal aphid population, biology, modelling and forecasting, a simulation study (to appear in Sim. Mon. Pudoc, Wageningen).

Fokkema, N. J., Kastelein, P. \& Post, B. J., 1979. No evidence for acceleration of leaf senescence by phyllosphere saprophytes of wheat. Trans. Br. mycol. Soc. 72: 2-5.

Pielou, E., 1969. An introduction to mathematical ecology. Wiley and Sons. New York.

Rabbinge, R., Ankersmit, G. W., Carter, N. \& Mantel, W. P., 1980. Epidemics and damage effects of cereal aphids in the Netherlands. Bull. SROP 1980/III/4: 99-106.

Rabbinge, R., Ankersmit, G. W. \& Pak, G. A., 1979. Cereal aphids, epidemiology and simulation of population development in winter wheat. Neth. J. Pl. Path. 85: 197-220.

Rabbinge, R., Drees, E. M., Graaf, M. van der, Verberne, F. C. M. \& Wesselo, A. M. Damage effects of cereal aphids in wheat (in preparation).

Rijsdijk, F. H., Rabbinge, R. \& Zadoks, J. C., in preparation (to appear in Sim. Mon. Pudoc, Wageningen).

Vereijken, P. H., 1979. Feeding and multiplication of three cereal aphid species and their effect on yield of winter wheat. Versl. landbouwk. Onderz. Ned. 888. Wageningen, $58 \mathrm{pp}$.

Wratten, S. D., 1975. The nature of the effects of the aphids Sitobion avenae and Metopolophium dirhodum on the growth of wheat. Ann. appl. Biol. 79: 27-34

\section{Addresses}

R.'Rabbinge, Department of Theoretical Production Ecology, Agricultural University P.O. Box 430, 6700AK Wageningen, the Netherlands.

W. P. Mantel, Research Institute for Plant Protection, P.O. Box 42, 6700AA Wageningen, the Netherlands. 


\section{Erratum}

J. H. Venekamp, A. Schepers and C. B. Bus: Mature plant resistance of potato against some virus diseases. III. Mature plant resistance against potato virus $\mathrm{Y}^{\mathrm{N}}$, indicated by decrease in ribosome-content in ageing potato plants under field conditions. Neth. J. Pl. Path. 86(1980) No 6: 301-309.

On pag 301, the fifth line from below should read: contents of these cell components. After a few weeks these contents decrease very 